\title{
PERTUMBUHAN DAN PRODUKSI 3 JENIS LEGUMINOSA POHON DI PERTANAMAN KELAPA PASCA DEFOLIASI
}

\author{
Growth and Production of 3 Types of Leguminosa Tree in Coconut Plantations After \\ Defoliation
}

\author{
Mohammad Takdir, Wardi, dan Andi Baso Lompengen Ishak \\ Balai Pengkajian Teknologi Pertanian Sulawesi Tengah \\ Email: dhirdhar31313@gmail.com
}

\begin{abstract}
INTISARI
Penelitian ini bertujuan untuk mengetahui pertumbuhan dan produksi indigofera, lamtoro, dan kaliandra di pertanaman kelapa pasca defoliasi. Penelitian dilaksanakan di Desa Bulubete, Kecamatan Dolo Selatan, Kabupaten Sigi, Sulawesi Tengah. Penelitian ini dilakukan pada 3 jenis legum yaitu indigofera (Indigofera sp.), lamtoro (Leucaena leucocephala), dan kaliandra (Calliandra calothyrsus). Variabel yang diamati meliputi tinggi tanaman (TT) dan produksi segar (PS) dari hasil panen pada hari ke-30, 60, dan 90. Data hasil penelitian dianalisis secara deskriptif. Hasil penelitian menunjukkan bahwa rata-rata produksi segar leguminosa yang dipanen pada umur 90 hari sebelum perlakuan pemupukan pada 3 jenis leguminosa: indigofera, lamtoro, dan kaliandra secara berturut-turut adalah $0,96 \mathrm{~kg} ; 0,37 \mathrm{~kg} ; 0,63 \mathrm{~kg}$; dan pasca pemupukan mencapai 5,50 sampai $7,66 \mathrm{~kg}$; 0,78 sampai $2,22 \mathrm{~kg}$; dan 2,0 sampai 3,28 kg. Disimpulkan bahwa introduksi dari ketiga leguminosa di bawah tegakan pertanaman kelapa yang paling adaptif adalah indigofera. Indigofera dapat dijadikan solusi alternatif terhadap permasalahan keterbatasan hijauan makanan ternak di peternakan rakyat.
\end{abstract}

Kata kunci: Indigofera, Lamtoro, Kaliandra, Pertanaman Kelapa, Pemupukan

\begin{abstract}
This research aimed to find out the growth and production of indigofera, lamtoro, and kaliandra in coconut plantations after defoliation. The study was conducted in Bulubete Village, South Dolo Subdistrict, Sigi Regency, Central Sulawesi. This study was conducted on 3 types of legumes, namely indigofera (Indigofera sp.), lamtoro (Leucaena leucocephala), and calliandra (Calliandra calothyrsus). Variables observed were plants height (TT) and fresh production yields (PS) on 30, 60, and 90 days. The results of data were analyzed descriptively. The results showed the average of fresh legumes production were harvested at the age of 90 days in 3 types of legumes: indigofera, lamtoro, and calliandra was $0.96 \mathrm{~kg} ; 0.37 \mathrm{~kg} ; 0.63 \mathrm{~kg}$; and post fertilization reaches 5.50 to 7.66 $\mathrm{kg} ; 0.78$ to $2.22 \mathrm{~kg}$; and 2.0 to $3.28 \mathrm{~kg}$. It was concluded that the introduction of three legumes under coconut stands that were very adaptive was indogofera. This can be used as an alternative solution for the limitations of forage in te small farms.
\end{abstract}

Keywords: Indigofera, Leucaena leucocephala, Calliandra, Coconut Plantations, Fertilization

\section{PENDAHULUAN}

Kurangnya ketersediaan pakan hijauan baik secara kualitas maupun kuantitas menjadi salah satu faktor penghambat keberhasilan usaha peternakan sapi potong, utamanya yang dikelola oleh peternak rakyat di pedesaan. Permasalahan ini diikuti pula dengan kondisi dimana sebagian besar usaha peternakan di pedesaan belum diikuti dengan upaya pengembangan hijauan makanan ternak (HMT) yang berkualitas. Menurut Prawiradiputra dan Priyanti (2009) hampir di seluruh wilayah produksi sapi, peternak rakyat mengalami masalah penyediaan dan pengadaan sumber hijauan makanan ternak yang efektif dan tersedia sepanjang tahun, salah satu penyebabnya adalah kemampuan 
suatu wilayah untuk menyediakan lahan guna menanam rumput introduksi semakin berkurang.

Di wilayah pedesaan potensi lahan produktif tapi belum termanfaatkan secara optimal relatif masih sangat luas, seperti lahan di antara tanaman kelapa. Umumnya lahan tersebut hanya ditumbuhi gulma dan rumput liar ataupun rumput alam yang kualitasnya rendah. Data BPS Provinsi Sulawesi Tengah (2017) menunjukkan bahwa luas perkebunan kelapa di Sulawesi Tengah mencapai 215.000 Ha. Dari total luasan tersebut diperkirakan $80 \%$ atau sekitar $172.000 \mathrm{Ha}$ masih dapat dimanfaatkan untuk pengembangan berbagai jenis HMT yang berkualitas. Pemanfaatan lahan di sela tanaman perkebunan sebagai areal penanaman hijauan makanan ternak sudah banyak dilakukan dan memberikan banyak keuntungan. Bamualim dan Subowo (2010) melaporkan bahwa pada lahan seluas 64.500 Ha sekitar 30\% dapat dijadikan areal penanaman HMT dengan daya dukung 19.350 ekor sapi.

Beberapa jenis tanaman HMT unggul serta tanaman lokal setempat dapat di introduksi pada lahan perkebunan untuk menghasilkan pakan berkualitas tinggi, baik sebagai sumber energi maupun sumber protein guna memenuhi kebutuhan makanan ternak. HMT dari jenis leguminosa pohon seperti indigofera (Indigofera zollingeriana), lamtoro (Leucaena leucocephala), dan kaliandra (Calliandra calothyrcus) merupakan jenis HMT sumber protein tinggi serta adaptif diintroduksikan pada lahan perkebunan kelapa, namun upaya introduksi tanaman hijauan di lahan perkebunan kelapa menyebabkan kompetisi penyerapan zat hara tanah, sehingga perlu tambahan pupuk baik untuk memenuhi kebutuhan tanaman kelapa maupun hijauan makanan ternak. Penelitian ini bertujuan untuk mengkaji tentang pertumbuhan dan produksi segar leguminosa pada umur 90 hari setelah pemupukan sebagai pengembangan HMT di perkebunan kelapa.

\section{MATERI DAN METODE}

Penelitian ini dilaksanakan di lahan milik anggota kelompok peternak Ramba Saluri Desa Bulubete, Kecamatan Dolo Selatan, Kabupaten Sigi, Sulawesi Tengah.

\section{Materi Penelitian}

Bahan yang digunakan dalam penelitian ini adalah indigofera, lamtoro, dan kaliandra, lahan untuk penanaman, air, pupuk $\mathrm{N}$ (urea), $P$ (TSP), dan ZA. Peralatan yang digunakan antara lain traktor, cangkul, tali ajir, meter, tali raffia, gunting stek, pisau/parang, timbangan, laptop, alat tulis menulis, dan kamera untuk dokumentasi.

\section{Metode Penelitian}

Penelitian ini dilakukan pada 3 jenis legum yaitu indigofera (Indigofera sp.), lamtoro (Leucaena leucocephala), dan kaliandra (Calliandra calothyrsus). Variabel yang diamati meliputi tinggi tanaman (TT) dan produksi segar (PS) dari hasil panen pada hari ke-30, 60, dan 90. Data hasil penelitian dianalisis secara deskriptif.

Penyiapan lahan diawali dengan pembersihan gulma, pengolahan lahan secara sempurna yakni pembajakan menggunakan traktor, pembalikan lapisan tanah dan kemudian dibiarkan beberapa hari. Selanjutnya tanah digemburkan dan dibuat bedengan sekaligus dibersihkan dari sisa-sisa perakaran gulma. Bedengan dibuat dengan ukuran lebar 1 meter dan panjang 20 meter mengarah dari Utara ke Selatan, dengan jarak antar bedengan 4 meter. Pembuatan bedengan sekaligus sebagai petak percobaan, sehingga pada lahan seluas $1.000 \mathrm{~m}^{2}$ tersebut terdapat 10 petak percobaan.

Penanaman. Penanaman 3 jenis leguminosa menggunakan jarak tanam $3 \times 3$ meter, jarak tanam dari tepi lebar dan panjang bedengan $50 \mathrm{~cm}$. Leguminosa pohon yang ditanam antara lain indigofera (Indigofera sp.), lamtoro (Leucaena leucocephala) dan kaliandra (Calliandra calothyrcus) berumur 75 hari di perbibitan dalam polybag. Penanaman dilakukan melalui tahapan yaitu pembuatan lubang tanam dengan menggunakan cangkul dengan kedalaman 15 sampai $20 \mathrm{~cm}$ dan diameter 10 sampai $15 \mathrm{~cm}$, penanaman dan penimbunan kembali dengan tanah. Untuk akurasi jarak tanam dan kelurusan barisan tanaman pada saat penanaman digunakan tali ajir yang telah ditandai sesuai ukuran jarak tanam.

Pemupukan. Pemupukan dilakukan setelah tanaman dipanen serentak pada umur 90 hari setelah tanam (HST) dengan dosis sesuai perlakuan, dengan cara dibenamkan 
dalam tanah dengan membentuk lingkaran pada setiap pohon tanaman.

Pemeliharaan. Pemeliharaan meliputi kegiatan penyiraman dilakukan pada pagi dan sore hari, kecuali pada saat musim hujan. Penyulaman dilakukan untuk mengganti tanaman yang mati atau pertumbuhannya yang kurang baik pada umur 21 HST. Kegiatan penting lainnya yaitu penyiangan dan pembersihan gulma yang dilakukan bersamaan dengan penggemburan tanah.

Defoliasi. Defoliasi pertama (sebelum perlakuan) saat tanaman berumur 90 HST. Defoliasi kedua (setelah perlakuan) dilakukan pada saat tanaman berumur 90 hari pasca pemupukan (HPP). Defoliasi dilakukan dengan cara pemotongan seluruh bagian tanaman (daun, cabang dan batang edibel) dengan menyisakan bagian utama tanaman setinggi 1,5 meter dari permukaan tanah.

Pengamatan sebelum perlakuan dilakukan pada hari ke 30, 60 dan 90 HST meliputi tinggi tanaman (TT), jumlah cabang (JC), dan produksi segar (PS). Jumlah sampel yang diamati sebanyak 25 pohon pada setiap jenis leguminosa. Teknik pengamatan dan pengambilan data dilakukan dengan cara yaitu tinggi tanaman diukur dengan menggunakan pita meter secara tegak lurus dari pemukaan tanah sampai puncak tajuk tertinggi pada setiap pohon tanaman, jumlah cabang dihitung berdasarkan jumlah cabang pada setiap pohon tanaman, produksi segar diukur dengan cara menimbang hasil defoliasi (daun dan batang) dari setiap pohon tanaman.

\section{HASIL DAN PEMBAHASAN}

\section{Tinggi Tanaman}

Hasil pengamatan pada 3 jenis leguminosa (indigofera, lamtoro, dan kaliandra) menunjukkan bahwa semua leguminosa relatif dapat beradaptasi pada pertanaman kelapa, hal ini terlihat dari tinggi tanaman dan jumlah cabang yang terus bertambah seiring pertambahan umur tanaman. Legum indigofera memperlihatkan pertumbuhan yang paling cepat dan produksi yang paling tinggi jika dibandingkan dengan lamtoro dan kaliandra (Tabel 1). Hal ini diduga karena indigofera mempunyai tingkat toleransi dan kemampuan adaptasi yang lebih baik pada kondisi lahan kering beriklim kering sebagaimana kondisi di pertanaman kelapa.

Hasil beberapa penelitian sebelumnya dilaporkan bahwa pada kondisi lingkungan yang sama indigofera lebih memiliki produksi biomasa yang tinggi bila dibandingkan dengan leguminosa pohon lainnya. Menurut Hassen et al. (2007) indigofera merupakan jenis tanaman leguminosa yang memiliki kandungan nutrisi dan produksi tinggi dan sangat toleran terhadap cekaman kekeringan, genangan, tanah asam, dan salin.

Sirait et al. (2009) menyatakan bahwa indigofera dapat berproduksi secara optimum pada umur 8 bulan. Rata-rata produksi biomasa segar indigofera sekitar 2,6 $\mathrm{kg} /$ panen/pohon, rasio produksi daun 967,75 g/panen/pohon (37,29\%), dan produksi batang 1627,25 g/panen/pohon $(63,57 \%)$ dengan total produksi segar sekitar 52 ton/Ha/tahun.

\section{Produksi Segar}

Menurut Shehu et al. (2001) rasio daun dan batang pada leguminosa pohon sangat penting. Daun pada leguminosa merupakan organ metabolisme. Rasio daun dan batang mempengaruhi kualitas leguminosa pohon. Semakin banyak jumlah daun maka kualitas leguminosa tersebut semakin baik, karena daun adalah bagian jaringan tanaman yang memiliki kandungan nutrien paling tinggidibandingkan dengan batang atau ranting.

Rata-rata pertumbuhan tiga jenis leguminosa pada Tabel 1. menunjukkan hasil yang berbeda. Tanaman indigofera menunjukan pertumbuhan yang relatif baik dibandingkan dengan tiga jenis leguminosa yang lain. Penyebabnya adalah indigofera memiliki tingkat toleransi dan mampu beradaptasi lebih baik pada kondisi lahan kering beriklim kering sebagaimana kondisi di lokasi pengkajian. Hasil penelitian sebelumnya menunjukkan bahwa pada kondisi lingkungan yang sama indigofera memiliki produksi biomasa yang lebih tinggi. Menurut Hassen et al. (2007) menyatakan bahwa indigofera merupakan jenis tanaman leguminosa yang memiliki kandungan nutrisi dan produksi tinggi serta sangat toleran terhadap cekaman kekeringan, genangan, dan tanah asam. 
Tabel 1. Rata-rata Pertumbuhan dan Berat Segar 3 Jenis Leguminosa Berdasarkan Umur Pengamatan

\begin{tabular}{lcccc}
\hline \multirow{2}{*}{ Parameter } & Umur Tanaman & \multicolumn{3}{c}{ Leguminosa } \\
\cline { 3 - 5 } & $(\mathrm{HST})$ & Indigofera & Lamtoro & Kaliandra \\
\hline \multirow{3}{*}{ Tinggi Tanaman (cm) } & 30 & $94,1 \pm 19,0$ & $32,9 \pm 4,9$ & $42,1 \pm 7,1$ \\
& 60 & $188,3 \pm 23,5$ & $78,3 \pm 8,9$ & $56,8 \pm 9,5$ \\
& 90 & $220,1 \pm 12,0$ & $84,2 \pm 5,7$ & $63,1 \pm 6,9$ \\
\hline \multirow{3}{*}{ Jumlah Cabang } & 30 & $5,9 \pm 1,0$ & $2,1 \pm 0,8$ & $3,7 \pm 0,5$ \\
& 60 & $28,2 \pm 5,1$ & $10,8 \pm 1,7$ & $14,6 \pm 3,6$ \\
& 90 & $27,1 \pm 3,3$ & $15,4 \pm 1,7$ & $17,7 \pm 2,1$ \\
\hline \multirow{2}{*}{ Produksi Segar } & 30 & $0,02 \pm 0,01$ & - & - \\
(kg/pohon) & 60 & $0,95 \pm 0,15$ & - & - \\
& 90 & $0,96 \pm 0,00$ & $0,3 \pm 0,0015$ & $0,63 \pm 0,0025$ \\
\hline
\end{tabular}

Tabel 2. memperlihatkan bahwa untuk semua perlakuan (P1, P2, P3, P4, dan P5) yang diujikan pada tiga jenis leguminosa di bawah pertanaman kelapa menunjukan bahwa indigofera menghasilkan produksi tertinggi (7,66 kg segar/pohon) dibandingkan dengan jenis leguminosa lainnya. Hal ini sejalan dengan Sirait et al. (2009) menyatakan indigofera dapat berproduksi secara optimum pada umur delapan bulan dengan rata-rata produksi biomasa segar per pohon sekitar $2,595 \mathrm{~kg} /$ panen, rasio produksi daun per pohon 967,75 g/panen (37,29\%) dan produksi batang per pohon $1627,25 \mathrm{~g} /$ panen $(63,57 \%)$ dengan total produksi segar sekitar 52 ton/ha/tahun.

Menurut Hassen et al. (2006) rata-rata produksi indigofera per panen produksi mencapai 2,6 ton $\mathrm{BK} / \mathrm{Ha} /$ tahun pada kondisi tanah asam. Sementara Abdullah (2010) melaporkan pada kondisi tanah podzolik merah kuning dengan $\mathrm{pH}$ netral produksi indigofera mencapai 4,096 ton BK/Ha/tahun pada umur 88 hari. Sebelumnya Ngo van Man et al. (1995) melaporkan bahwa produksi bahan kering indigofera dari 3 kali panen pada umur 16 bulan mencapai sebesar 8,423 $\mathrm{kg} / \mathrm{Ha}$.

Rataan berat segar yang dihasilkan dari indigofera terkecil 5,5 kg segar/pohon jika dikalikan dengan jumlah pohon yang ditanam di sela pertanaman kelapa dalam $1 \mathrm{Ha}$ dapat menghasilkan HMT sekitar 2,20 ton segar/Ha. Jika ini di koversi ke satuan ternak (ST), maka satu ST disetarakan dengan satu ekor sapi potong atau perah (Ashari et al., 1999) yang diasumsikan setara dengan bobot badan 350 kg yang mengkonsumsi $35 \mathrm{~kg}$ HMT segar. Jika kebutuhan pakan ternak sapi potong dewasa membutuhkan hijauan sebanyak $35 \mathrm{~kg}$ segar/ekor/hari, maka dalam 1 Ha HMT indigofera yang dihasilkan dapat mencukupi kebutuhan pakan ternak sapi potong dewasa sebanyak 62,8 ST.

Tabel 2. Rata-rata Produksi Segar 3 Jenis Leguminosa Pada Umur Defoliasi 90 HPP

\begin{tabular}{lccccc}
\hline \multirow{2}{*}{\multicolumn{1}{c}{ Jenis Leguminosa }} & \multicolumn{5}{c}{ Perlakuan Pemupukan } \\
\cline { 2 - 6 } & $\mathrm{P} 1$ & $\mathrm{P} 2$ & $\mathrm{P} 3$ & $\mathrm{P} 4$ & $\mathrm{P} 5$ \\
\hline Indigofera (kg/pohon) & $5,5 \pm 2,6$ & $7,48 \pm 3,1$ & $5,20 \pm 2,7$ & $7,66 \pm 1,4$ & $4,78 \pm 1,4$ \\
Lamtoro (kg/pohon) & $1,72 \pm 0,7$ & $1,54 \pm 0,9$ & $2,22 \pm 1,0$ & $1,20 \pm 0,6$ & $0,78 \pm 0,3$ \\
Kaliandra (kg/pohon) & $2,30 \pm 1,2$ & $3,28 \pm 0,7$ & $2,84 \pm 0,7$ & $2,0 \pm 0,6$ & $2,26 \pm 0,7$ \\
\hline
\end{tabular}

\section{KESIMPULAN}

Hasil penelitian menunjukkan bahwa rata-rata produksi segar leguminosa yang dipanen pada umur 90 hari sebelum perlakuan pemupukan pada 3 jenis leguminosa: indigofera, lamtoro, dan kaliandra secara berturut-turut adalah 0,96 kg; 0,37 kg; 0,63 kg; dan pasca pemupukan mencapai 5,50 sampai $7,66 \mathrm{~kg} ; 0,78$ sampai 2,22 kg; dan 2,0 sampai 3,28 kg. Disimpulkan bahwa introduksi dari ketiga leguminosa di bawah tegakan pertanaman kelapa yang paling adaptif adalah indigofera. Indigofera 
dapat dijadikan solusi alternatif terhadap permasalahan keterbatasan hijauan makanan ternak di peternakan rakyat.

\section{UCAPAN TERIMA KASIH}

Ucapan terimakasih kepada Pengurus dan seluruh anggota kelompok peternak Ramba Saluri Desa Bulubete, Kecamatan Dolo Selatan, Kabupaten Sigi atas kerjasama yang baik selama kegiatan penelitian dilaksanakan.

\section{DAFTAR PUSTAKA}

Abdullah, L. 2010. Herbage production and quality of shrub indigofera treated by different concentration of foliar fertilizer. Media Peternakan. 33(3):169175.

Ashari, F., E. Juarini, Sumanto, B. Wibowo, dan Suratman, 1995. Pedoman Analisis Potensi Wilayah Penyebaran dan Pengembangan Peternakan. Balai Penelitian Ternak dan Direktorat Bina Penyebaran dan Pengembangan Peternakan. Jakarta

Badan Pusat Statistik Provinsi Sulawesi Tengah. 2017. Provinsi Sulawesi Tengah Dalam Angka 2017. Badan Pusat Statistik Provinsi Sulawesi Tengah. Sulawesi Tengah.

Bamualim A, dan G. Subowo. 2010. Potensi dan Peluang Pengembangan Ternak Sapi di Lahan Perkebunan Sumatera Selatan. Prosiding Lokakarya Pengembangan Sistem Integrasi Kelapa Sawit-Sapi. Pusat Penelitian dan Pengembangan Peternakan. Badan Litbang Pertanian. Kementerian Pertanian. Jakarta.

Hassen, A., N.F.G. Rethman, dan Z. Apostolides. 2006. Morphological and agronomic characterization of Indigofera species using multivariate analysis. Tropical Grasslands. 40(1):45-59.

Hassen, A., N.F.G. Rethman, W.A. van Niekerk and T.J. Tjelele. 2007. Influence of season/year and species on chemical composition and in vitro digestibility of five Indigofera accessions. Animal Feed Science Technology. 136(3):312-322.

Ngo van Man, Nguyen van Hao, and Vuong minh Tri. 1995. Biomass production of some leguminous shrubs and trees in Vietnam. Livestock Research for Rural Development. 7(2):1-5.

Prawiradiputra, B.R. dan A. Priyanti, 2009. Teknologi Pasokan Hijauan Pakan Yang Berkelanjutan Mendukung Pengembanganusaha Sapi Perah di Indonesia. Prosiding Semiloka Nasional Prospek Industri Sapi Perah Menuju Perdagangan Bebas 2020. Hal. 107-114.

Prawiradiputra, B.R., S. Endang, Sajimin, dan F. Achmad. 2012. Hijauan Pakan Ternak Untuk Lahan Sub-Optimal. Badan Penelitian dan Pengembangan Pertanian. IAARD Press. Bogor.

Shehu, Y., W. Alhassan, U.R. Pal, and C.J.C. Phillips. 2001. Yield and chemical composition response of Lablab purpureus to nitrogen, phosphorus and potassium fertilizers. Tropical Grasslands. 35:180-185.

Sirait. J., K. Simanihuruk, and R. Hutasoit. 2009. The potency of Indigofera sp. as goat feed: production, nutritive value and palatability. In: Proceeding of International Seminar on Forage Based Feed Resources. Bandung, 3-7 Agustus 2009. Taipei (Taiwan): Food and Fertilizer Technology Centre (FFTC) ASPAC, Livestock Research Centre-COA, ROC and IRIAP. p.4-7. 